\title{
Quality characteristics of hot-air dried 'Darae' (Actinidia arguta) with different sugar osmotic dehydration pretreatment
}

\author{
Ji-Young Choi ${ }^{1}$, Jiyoon Kim ${ }^{1}$, Jungsoo Kim ${ }^{1}$, Saeul Jeong ${ }^{1}$, Kyeom Ju Yun ${ }^{1}$, \\ Jihye Kim ${ }^{1}$, Jong Tae Moon ${ }^{2}$, Kwang-Deog Moon ${ }^{1 *}$ \\ ${ }^{1}$ School of Food Science and Technology, Kyungpook National University, Daegu 41566, Korea \\ ${ }^{2}$ Forest Resources Development Institute of Gyeongsangbuk-do, Andong 36691, Korea \\ 당 삼투건조 전처리를 달리한 열풍건조 다래의 품질 특성

\begin{abstract}
최지영 ${ }^{1} \cdot$ 김지윤 $^{1} \cdot$ 김정수 $^{1} \cdot$ 정새울 $^{1} \cdot$ 윤겸주 $^{1} \cdot$ 김지혜 $^{1} \cdot$ 문종태 $^{2} \cdot$ 문광덕 $^{1 *}$
1경북대학교 식품공학부 식품생물공학전공, ${ }^{2}$ 경상북도 산림자원개발원 자원개발과
\end{abstract}

\begin{abstract}
In this study, various osmosis pretreatments were performed and the quality characteristics were compared in order to develop the optimal hot-air dried 'Darae' product. Treatment groups were osmoticized with sugar (SUC) and sorbitol (SOR), and were divided according to the presence or absence of ascorbic acid treatment at $30^{\circ} \mathrm{C}$ and $55^{\circ} \mathrm{C}$, respectively. The SOR groups showed high weight reduction (\%) and low moisture content. Among the SUC groups the treatments added with ascorbic acid added at $55^{\circ} \mathrm{C}$ showed high drying efficiency. The browning of fruits was more severe in the SOR, and as a result of the physical property analysis, the SUC tended to have a lower hardness and the flesh was soft. The total flavonoid contents and DPPH scavenging activity were high in the SUC groups, and especially the ascorbic acid treatment groups showed significantly higher antioxidant activity. Sensory evaluation showed that, there was no significant difference in sweetness or sourness, and in terms of appearance, SUC groups scored high. Therefore, it is appropriate to use an osmotic-dried solution of a $55^{\circ} \mathrm{C}$ sugar osmosis solution added with ascorbic acid for manufacturing the optimal dried sputum with both palatability, functionality, and drying efficiency.
\end{abstract}

Key words : Actinidia arguta, dried snack, osmotic dehydration, sugar, sorbitol

\section{서 론}

토종다래(Actinidia arguta)는 다래나무과(Actinidiaceae)에 속하는 낙엽활엽의 다년생 덩굴식물로 우리나라 산지 전역과 일본과 중국 등에 분포하며, 어느 곳에서나 잘 성장하는 특징 이 있다(Kim 등, 2016). 토종다래는 크기는 작지만, 고분자류 가 많이 포함된 외피까지 함께 식용이 가능하고, 당도가 높아 기호성이 좋으며, 무기영양소, 비타민 C 함량이 높다(Park 등, 2011). 하지만 키위에 비해 소비자와 생산자에게 보급 및
홍보가 되지 못하여 그 이용률이 매우 저조한 실정이며, 후숙 되면서 과육이 물러져 쉽게 손상되므로, 유통 및 저장 중 품 질이 급격히 저하되는 어려움이 있다(Fisk 등, 2006). 이렇게 수분이 많은 과채류들은 미생물의 번식, 외관 변질 등의 문제 로 인해 장기간 저장에 취약하며, 때문에 수분으로 인한 영향 을 줄여 장기간 저장 및 유통을 가능하게 하는 건조공정을 많이 사용한다(Dev와 Raghavan, 2012). 다래의 건조 가공공 정에 관한 기존 연구로는 가식성 코팅처리를 한 동결건조 스 낵(Kim 등, 2016), 열풍 건조 가공 공정이 다래의 산화 방지

*Corresponding author. E-mail : kdmoon@knu.ac.kr, Phone : +82-53-950-5773, Fax : +82-53-950-6772

Received 23 November 2020; Revised 01 February 2021; Accepted 17 March 2021.

Copyright (c) The Korean Society of Food Preservation.

This is an Open Access article distributed under the terms of the Creative Commons Attribution Non-Commercial License (http://creativecommons.org/licenses/by-nc/4.0) which permits unrestricted non-commercial use, distribution, and reproduction in any medium, provided the original work is properly cited. 
능에 미치는 영향(Jin 등, 2015) 등이 있으나, 아직까지 추가 적인 연구가 미흡하여 제품화 비율이 낮은 편이다. 여러 가지 건조방법 중에서도 열풍건조는 국내에서 가장 흔하고 쉽게 사용하고 있는 건조방법이다. 열풍건조는 건조실 내 열풍의 체류시간이 짧고, 배출되는 열풍의 열량이 크므로 에너지 효 율이 낮으며, 열풍에 의해 제품의 향기나 무기질 등이 파괴되 어 영양적 손실과 함께 표면 경화의 단점이 있으나(Lee 등, 2000), 경제적으로 저렴하다는 장점을 가지고 있다. 또한 부 서지는 동결건조의 식감과는 다르게 쫀득한 식감을 내는 건조 스낵을 제조할 수 있다. 하지만 열풍건조다래는 건조 시 갈변 이 발생하며, 단맛보다 신맛이 강조되며, 특유의 향으로 인해 기호성이 떨어질 수 있다. 이러한 문제를 해결하기 위하여 다 래 건조공정에서 적용시킬 수 있는 방식이 삼투건조이다.

삼투건조(osmotic dehydration)는 고농도의 용액에 건조하 고자 하는 식품을 넣어 삼투압의 원리로 건조 대상 속 수분함 량을 낮추고, 고농도 용액 속에 존재하는 용질(소금, 설탕, 폴 리올 등)을 침투시키는 공정이다(Lewicki와 Lenart, 2006). 삼투처리는 비용이 적게 들고 간단하다는 장점을 가지고 있 으며, 건조 시간을 단축시켜 건조효율성 증가, 온도에 의한 품질 저하 방지 등의 효과가 있다(Kim, 1990). 또한 당이나 염 성분이 식품 수분이 빠져나간 자리에 침투되어 맛을 개선 시킬 수 있으므로 건조공정의 전처리로서 많이 사용된다 (Ahmed 등, 2016). 이전에 사과의 열풍 및 동결건조(Kim 등, 2011a), 건조 단호박 제조(Na 등, 2004), 건조 아로니아 제조 (Bae 등, 2020) 등의 연구에서 삼투건조가 이용되었다.

따라서 본 연구에서는 국내 재배되는 다래의 소비량을 높 이고, 다래 농가 및 시장의 경제 회복을 위하여 다양한 조건 의 당 삼투 처리 열풍건조 다래를 제조하였으며, 건조 효율성 및 관능적 기호도를 향상시켜 최적의 열풍건조 다래 제품을 개발하는 것을 목적으로 하였다.

\section{재료 및 방법}

\section{실험재료 및 전처리}

시료는 청도 운문면에서 2020년 10월에 수확된 다래를 6 일 후숙시킨 후 사용하였다. 후숙된 다래 중 실험 결과의 오 차를 줄이기 위하여 $11.00 \pm 1.00 \mathrm{~g}$ 의 과실을 선별하였다. 삼 투용 당으로는 백설탕 $(100 \%, \mathrm{CJ}$, Incheon, Korea), 솔비톨 (Shijiazhuang Ruixue Pharmaceutical Co., Ltd., Hebei, China)을 사용하였다. 본 실험에서는 설탕 및 솔비톨을 사용 하여 각각 $50{ }^{\circ} \mathrm{Brix}$ 의 고농도 삼투 용액을 제조하였다. 각각 의 제조한 고농도 삼투 용액 $1 \mathrm{~L}$ 에 선별된 다래를 잠기도록 한 뒤, 3 시간 동안 삼투건조를 진행하였다. Ascorbic acid 처 리구는 삼투용액 $1 \mathrm{~L}$ 의 $2 \%$ 인 $20 \mathrm{~g}$ 을 삼투용액에 첨가하여
Table 1. Sample labels and osmotic dehydration pretreatment conditions of Actinidia arguta

\begin{tabular}{|c|c|c|}
\hline Label & Dipping solution & Temperature $\left({ }^{\circ} \mathrm{C}\right)$ \\
\hline CONT & No treatment & - \\
\hline SUC3O & $\begin{array}{l}\text { Sucrose } 50{ }^{\circ} \text { Brix solution with } \\
2 \% \text { ascorbic acid }\end{array}$ & 30 \\
\hline SUC3X & Sucrose $50^{\circ}$ Brix solution & 30 \\
\hline SUC5O & $\begin{array}{l}\text { Sucrose } 50{ }^{\circ} \text { Brix solution with } \\
2 \% \text { ascorbic acid }\end{array}$ & 55 \\
\hline SUC5X & Sucrose $50{ }^{\circ}$ Brix solution & 55 \\
\hline SOR3O & $\begin{array}{l}\text { Sorbitol } 50{ }^{\circ} \text { Brix solution with } \\
2 \% \text { ascorbic acid }\end{array}$ & 30 \\
\hline SOR3X & Sorbitol $50^{\circ}$ Brix solution & 30 \\
\hline SOR5O & $\begin{array}{l}\text { Sorbitol } 50{ }^{\circ} \text { Brix solution with } \\
2 \% \text { ascorbic acid }\end{array}$ & 55 \\
\hline SOR5X & Sorbitol $50^{\circ}$ Brix solution & 55 \\
\hline
\end{tabular}

녹인 것이다. 실험 처리구에 대한 자세한 설명은 Table 1에 나타내었다. 삼투건조 후 다래를 건져내어 30 분간 탈수 후 $55^{\circ} \mathrm{C}$ 로 설정된 열풍건조기(Kiturami drying machine, KED$132 \mathrm{~A}$, Kiturami, Seoul, Korea)에 펴 21시간 동안 열풍 건조 시켰다. 열풍건조 조건(온도, 시간)은 사전 연구를 통해 결정 되었다.

시약은 2,2-dipheny-1-picrylhydrazyl(Sigma-Aldrich, St. Louis, MO, USA), Folin-Ciocalteu's regent(Junsei, Tokyo, Japan), gallic acid(Sigma-Aldrich), naringin(Sigma-Aldrich), $\mathrm{Na}_{2} \mathrm{CO}_{3}$ (Duksan Pure Chemicals Ltd., Ansan, Korea), diethylene glycol(Samchun Pure Chemicals Co., Seoul, Korea), 1N $\mathrm{NaOH}$ (Duksan Pure Chemicals Ltd.), ethyl alcohol (Duksan Pure Chemicals Ltd.), sulfuric acid 98\%(Daejung Chemicals \& Metals, Siheung, Korea), ascorbic acid(Duksan Pure Chemicals Ltd.)을 사용하였다.

\section{삼투건조 mass transfer 및 수분함량 측정}

삼투건조 전 · 후 총 다래의 무게 변화를 측정하고, 삼투에 의한 수분함량 변화를 확인하기 위해 Nowicka 등(2015)의 방법을 이용하여 다음과 같은 식을 이용해 중량 감소율을 계 산했다. 이 모든 과정은 1 반복으로 수행되었다.

Weight reduction $=\left(\mathrm{w}_{0}-\mathrm{w}_{\mathrm{d}}\right) / \mathrm{w}_{0} \times 100(\%)$

$\mathrm{w}_{0}$ : 처음 시료 무게

$\mathrm{w}_{\mathrm{d}}$ : 삼투건조 후 시료 무게 
건조한 다래는 식혀 열기를 없앤 후, 식품공전 일반시험 법의 건조 감량법을 사용하여 수분함량을 3 반복 분석하였 다. 당분을 많이 함유한 시료이므로 $103^{\circ} \mathrm{C}$ 에서 45 시간 건 조하여 다음 식으로 계산 후 \%로 나타내었다.

Moisture content $=\left(\mathrm{w}_{0}-\mathrm{w}_{\mathrm{s}}\right) / \mathrm{w}_{0} \times 100(\%)$

$\mathrm{W}_{0}$ : 처음 시료 무게

$\mathrm{w}_{\mathrm{s}}$ : 건조 후 시료 무게

\section{색도 측정}

열풍건조 다래의 외관을 평가할 수 있는 색도는 백색판 ( $\mathrm{L}^{*}=97.79, \mathrm{a}^{*}=-0.38, \mathrm{~b}^{*}=2.05$ )으로 보정된 colorimeter(CR-400, Konica Minolta Co., Osaka, Japan)로 측정하였으며, 명도 ( $\mathrm{L}^{*}=$ lightness), 적색도 $\left(\mathrm{a}^{*}=\mathrm{redness}\right)$, 황색도( $\mathrm{b}^{*}=$ yellowness $)$ 로 나타냈다. 건조 다래 표면의 중앙부분을 측정부위로 하였 으며, 분석은 18 번 반복하였다.

\section{가용성 고형분 및 $\mathrm{pH}$ 측정}

가용성 고형분 및 $\mathrm{pH}$ 는 세절된 시료와 증류수를 $1: 2(\mathrm{w} / \mathrm{v})$ 로 혼합한 뒤 균질기(Homogenizer, JP/AM-9, Nihonseiki kashima, Japan)로 마쇄한 뒤, 거즈로 거른 여액으로 분석하 였다. $\mathrm{pH}$ 는 $\mathrm{pH}$ meter $(\mathrm{pH} 510$ benchtop meter, Oakton Instrument, Vernon Hills, IL, USA)로 측정하였으며, 가용성 고형분 함량은 굴절 당도계(master- $\alpha$. Atago Co., Tokyo, Japan)를 이용하여 측정하고, ${ }^{\circ} \mathrm{Brix}$ 로 나타내었다. 희석배수 는 결과 값에 별도로 반영하지 않았다.

\section{조단백 함량 분석}

열풍건조 다래의 조단백 함량은 식품의약품안전처에서 고 시한 일반시험법의 총질소 및 조단백질 분석법을 변용하여 질 소자동분석기(Nitrogen Autoanalyzer, TZ-controller, Gerhardt, Konigswinter, Germany)를 통해 분석되었다. 먼저 분해 장치 에서 촉매(Kjeldahl catalyst tabs, KJELCAT ${ }^{\mathrm{TM}} \mathrm{SE}$, Konigswinter, Germany)의 존재 하에서 황산(Daejung Chemicals \& Metals, Siheung, Korea)을 가하여, 시료의 질소를 황산암모늄 으로 가열 분해하였다. 다음 증류 및 적정장치를 통해 황산암 모늄에 $\mathrm{NaOH}$ 를 가하고, 포집액을 $\mathrm{NaOH}$ 로 적정하여 질소 양 을 구하고, 질소 계수 6.25 를 곱하여 조단백 양을 산출하였다.

\section{유리당 함량 분석}

열풍건조 다래의 단맛, 풍미를 결정짓는 유리당 및 유기산 함량을 분석하였다. 시료 $4 \mathrm{~g}$ 에 증류수 $36 \mathrm{~mL}$ 를 가하고, 24 시간 동안 $40^{\circ} \mathrm{C}$ 의 shaking incubator에서 $160 \mathrm{rpm}$ 으로 추출
하였다. 추출 후 Whatman No.4로 여과한 뒤, 여액을 $0.45 \mu \mathrm{m}$ 실린지 필터로 재여과하여, 유리당 및 유기산 함량 분석 시액 으로 사용하였다. 유리당은 high performance liquid chromatography(HPLC, Alliance Waters Co., Milford, MA, USA) 으로 정량하였으며, 이동상은 $0.01 \mathrm{M} \mathrm{Ca-EDTA}(50 \mathrm{mg} /$ 1ld. $\left.\mathrm{H}_{2} \mathrm{O}\right)$, Column은 Sugar-Pak I column $(\varnothing 6.5 \times 300 \mathrm{~mm}$, Waters Co.)을 사용하였다. Detector는 refractive index (Shimadzu, Kyoto, Japan), 이동상의 온도는 $90^{\circ} \mathrm{C}$, 유속은 0.5 $\mathrm{mL} / \mathrm{min}$ 로 설정하였다. 유기산은 High performance liquid chromatography(Shimadzu Co., Model Prominence)로 정량 하였으며, 이동상은 $0.005 \mathrm{M} \mathrm{H}_{2} \mathrm{SO}_{4}$ in water, column은 PL Hi-Plex H(Ø 7.7×300 mm, Agilent Technologies, Santa Clara, $\mathrm{CA}, \mathrm{USA}$ )를 사용하였다. 칼럼 온도는 $65^{\circ} \mathrm{C}$, 이동상의 유속은 $0.6 \mathrm{~mL} / \mathrm{min}$ 로 설정되었고, detector는 RI model RID-10A (Shimadzu Co.)를 사용하였다. 샘플은 유리당과 유기산 모두 $20 \mu \mathrm{L}$ 를 주입하였고, 결과는 $\mathrm{mg} / \mathrm{mL}$ 로 나타내었다.

\section{물성 측정}

당삼투 전처리를 달리한 열풍건조 다래의 조직감을 분석하 기 위해 Rheometer(Compac-100II, SunScientific Co., Tokyo, Japan)를 이용하였다. Prove는 직경 $5 \mathrm{~cm}$ 인 것을 사용하였으 며, 샘플과 prove의 간격은 $3 \mathrm{~mm}$, table speed는 $120 \mathrm{~mm} / \mathrm{min}$, 진입 깊이는 $4.00 \mathrm{~mm}$ 로 설정하였다. 분석 항목은 strength, hardness, springness, cohesiveness, gumminess, brittleness, adhesiveness이며, 처리구당 5 회 측정한 값을 평균하여 나타 내었다.

\section{항산화능 측정}

다양한 건조 다래의 항산화능을 비교하기 위하여 $\mathrm{DPPH}$ 소거능(2,2-dipheny-1-picrylhydrazyl scavenging activity)과, total flavonoid content(TFC)를 분석하였다. 세절한 시료 $5 \mathrm{~g}$ 에 에탄올 $70 \% 45 \mathrm{~mL}$ 를 첨가한 후, 24 시간 동안 $40^{\circ} \mathrm{C}$ 의 shaking incubator에서 $160 \mathrm{rpm}$ 으로 추출하였다. 추출 후 Whatman No.4로 여과한 뒤, 회전 감압농축기(RV 10 Digital, IKA, Staufen, Germany)를 이용하여 용매를 휘발시켰다. 남 은 고형분에 일정한 농도로 맞추기 위하여 에탄올 $70 \%$ 를 가 하여 녹인 것을 시액으로 사용하였다.

$\mathrm{DPPH}$ 은 Brand-Williams 등(1995)의 방법에 따라 측정하였 다. $70 \%$ 에탄올로 흡광도 값이 $0.800-0.850$ 이 되도록 $\mathrm{DPPH}$ solution을 보정하여 제조하였으며, 희석된 건조 다래 에탄올 추출물에 DPPH solution를 1:9로 혼합하고, 20 분간 암실에 서 정치 후 spectrophotometer(Evolution 201 UV-Visible Spectrophotometer, ThermoFisher Scientific, Brooklyn, NY, $\mathrm{USA}$ 를 이용하여 $517 \mathrm{~nm}$ 에서 흡광도를 측정하였다. 
TFC는 시액의 9 배에 해당하는 diethylene glycol을 가한 후 $1 \mathrm{~N} \mathrm{NaOH}$ 를 첨가하고, $37^{\circ} \mathrm{C}$ 에서 1 시간 동안 방치 후 420 nm에서 UV-Vis spectrophotometer(Evolution 201 UV-Visible spectrophotometer, ThermoFisher Scientific)를 이용하여 흡 광도를 측정하였다. Naringin(Sigma-Aldrich) 표준물질로 검 량선을 작성하였다.

\section{관능검사}

관능검사는 훈련된 경북대학교 대학생 및 대학원생 9 명을 대상으로 실시하였으며, 외관(appearance), 단맛(sweetness), 신맛(sourness), 냄새(smell), 식감(texture), 종합적 기호도 (Overall) 항목으로 나누어 7점법을 기준으로 절대평가하도 록 하였다. 단맛과 신맛 항목은 강할수록 높은 점수를, 외관, 냄새, 식감, 종합적 기호도 항목은 기호에 따라 높은 점수를 주도록 하였다. 또한 기호성 항목들은 상품적 가치가 없다고 판단될 시 3점 이하로 점수를 부여하도록 하였다. 본 관능검 사는 경북대학교 생명윤리심의위원회에서 최종 면제 승인을 받고 안전하게 진행하였다(접수번호: 2020-0142).

\section{통계처리}

모든 실험은 3 회 이상 반복하여 진행되었다. 실험결과는 평균과 표준편차로 표기하였으며, SPSS software package (Version, SPSS Inc., Chicago, IL, USA) 프로그램을 이용하 여 분산분석(ANOVA)과 Duncan 다중검위검정(Duncan's multiple range test)을 실시하였다 $(\mathrm{p}<0.05)$.

\section{결과 및 고찰}

\section{삼투건조 mass transfer}

당삼투 전처리 후 다래의 중량 감소율을 측정한 결과는 Fig. 1에 나타내었다. Matuska 등(2006)의 연구에 따르면, 삼 투건조 공정의 조건에 따라 시료 수분의 $10 \%$ 에서 최대 $70 \%$ 까지 제거할 수 있었다고 한다. $\mathrm{SUC} 3 \mathrm{O}$ 와 $\mathrm{SOR} 3 \mathrm{O}$ 는 값이 유 사하였고, SUC5O와 SOR5O는 서로 유사하였다. Ascorbic $\mathrm{acid}$ 를 첨가하였을 때는 같은 온도에서 감미료에 따른 $\mathrm{WR}$ 의 차이는 나타나지 않았으나, ascorbic acid를 첨가하지 않았을 때는 같은 온도에서 WR 차이가 크게 나타났다. 설탕과 솔비 톨의 분자량은 각각 $342.30 \mathrm{~g} / \mathrm{mol}, 182.17 \mathrm{~g} / \mathrm{mol}$ 로 설탕이 약 두 배의 분자량을 가졌다. 본 연구에서 나타난 WR의 결과는 삼투 건조 시 solute agent의 분자량이 작을수록 더 많은 수분 함량이 손실된다(Phisut, 2012)는 이전 연구결과와 유사하였다. 또한 ascorbic acid의 몰 질량은 $176.12 \mathrm{~g} / \mathrm{mol}$ 로 솔비톨의 몰 질량 $(182.17 \mathrm{~g} / \mathrm{mol})$ 과 유사하다. 설탕 처리구에서는 ascorbic acid가 설탕에 비해 분자량이 매우 작아 과피에 쉽게 흡수될 수 있어, SUC3X와 SUC5X보다 SUC3O, SUC5O에서 삼투 효과가 증대될 수 있었을 것으로 보인다. 일부 구간에서 마이 너스 값이 나온 것은 삼투건조 전보다 후의 무게가 더 높아진 것을 나타내며, 이는 삼투건조 시 과육 안에서 밖으로 수분이 이동되는 양보다 과육 밖에서 안으로 당 용액의 이동이 더 컸 기 때문에 나타나는 현상이다(Hong 등, 1998). 이러한 결과를 통해 $30^{\circ} \mathrm{C}$ 처리 시료보다 $55^{\circ} \mathrm{C}$ 처리 시료에서 무게 감소현상

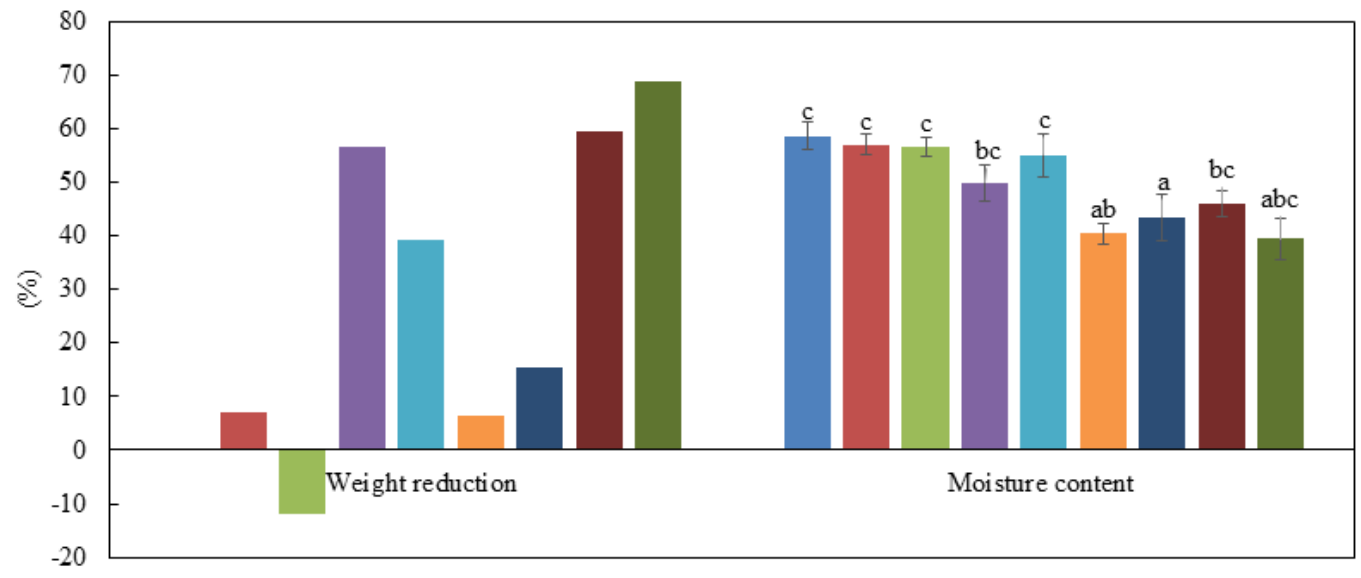

$\approx \mathrm{CONT}=\mathrm{SUC} 3 \mathrm{O}=\mathrm{SUC} 3 \mathrm{X}=\mathrm{SUC5O}=\mathrm{SUC} 5 \mathrm{X}=\mathrm{SOR} 3 \mathrm{O}=\mathrm{SOR} 3 \mathrm{X}=\mathrm{SOR} 5 \mathrm{O}=\mathrm{SOR} 5 \mathrm{X}$

Fig. 1. Weight reduction (WR) and moisture content of hot-air dried Actinidia arguta by various pretreatment of osmotic dehydration. CONT, no treatment; SUC3O, sucrose $50{ }^{\circ}$ Brix solution with ascorbic acid $2 \%$ in $30^{\circ} \mathrm{C}$; SUC3X, sucrose $50{ }^{\circ}$ Brix solution in $30^{\circ} \mathrm{C}$; SUC5O, sucrose $50{ }^{\circ}$ Brix solution with ascorbic acid $2 \%$ in $55^{\circ} \mathrm{C}$; SUC5X, sucrose $50{ }^{\circ}$ Brix solution in $55^{\circ} \mathrm{C}$; SOR3O, sorbitol $50{ }^{\circ}$ Brix solution with ascorbic acid $2 \%$ in $30^{\circ} \mathrm{C}$; SOR3X, sorbitol $50^{\circ}$ Brix solution in $30^{\circ} \mathrm{C}$; SOR5O, sorbitol $50{ }^{\circ}$ Brix solution with ascorbic acid $2 \%$ in $55{ }^{\circ} \mathrm{C}$; SOR5X, sorbitol $50{ }^{\circ}$ Brix solution in $55^{\circ} \mathrm{C}$.

Values followed by different small letters $\left(^{a-c}\right)$ are significantly different at $\mathrm{p}<0.05$ based on Duncan's multiple range test according to the group. 
이 크게 된것을 확인하여, 고온에서 솔비톨의 삼투효과가 더 욱 크게 나타나는 것을 확인했다.

\section{수분함량}

수분함량은 전반적으로 솔비톨 전처리 시 유의적으로 현 저히 낮은 것을 확인하였으며, 설탕과 솔비톨의 사용에 따른 수분함량 차이는 크게 나타났으나, 전처리 온도나 ascorbic acid의 유무가 건조 정도에 영향을 크게 미치지 않았다. 위의 결과로 미루어볼 때, 솔비톨 삼투 처리 시, 건조 효율성이 좋 아졌으며, WR과 수분함량이 반비례 경향을 보이지 않는 것 을 보아, 수분뿐만 아니라 다른 유효성분들이 다소 유출된 것 으로 예상된다. 또한 $\mathrm{SUC5O}$ 와 $\mathrm{SUC5X}$ 는 $\mathrm{SUC} 3 \mathrm{O}$ 와 $\mathrm{SUC} 3 \mathrm{X}$ 에 비하여 수분함량이 낮았는데, 이는 단호박과 사과, 키위의 당 삼투건조 공정에서 침지온도가 증가할수록 내부의 수분확 산이 향상되고, water loss가 높아 삼투효과, 건조효과가 컸다 는 연구 결과와 일치하였다(Hong 등, 1998; Na 등, 2004; Saurel 등, 1994).

\section{조단백 함량}

열풍건조 다래의 조단백 함량을 측정한 결과는 Table 2에 표시하였다. 2018년 강원도농업기술원 자료에 따르면, 평균 단백질 함량은 0.98-1.13 g/100 g으로 나타냈으며, 본 연구에 서 건조 이후 수분함량의 비율이 감소하면서 단백질 비율이
증가하였다. SUC5O와 SOR5X는 각각 $3.42 \%, 3.13 \%$ 로 유 의적으로 낮은 조단백 함량을 나타냈으며, SOR3X는 $5.02 \%$ 로 가장 높은 함량을 나타내었다. 나머지 처리구들은 눈에 띄 는 차이 없이 값이 유사하였다. Fig. 1에서 보면, SUC5O가 수분함량이 다른 설탕처리구들보다 낮은 것을 확인할 수 있 는데, 조단백 함량도 비슷한 경향을 보였으나, 솔비톨 처리구 는 수분함량과 비례하지는 않았다. 설탕 처리구에 비하여 솔 비톨 처리 시, SOR5X를 제외하고는 수분함량에 비해 조단 백 유출이 적게 되는 것으로 보인다. 또한 처리한 당 종류나 ascorbic acid 첨가가 건조 다래의 조단백질 함량에 영향을 주지 않았다.

\section{색도}

다양한 열풍건조 다래의 색도 결과는 Table 2에 나타내었 다. 전반적으로 설탕 삼투 전처리를 한 시료들의 $\mathrm{L} *$ 와 $\mathrm{b}$ *값 이 각각 46.08-48.99, 24.73-26.59로 솔비톨 삼투 전처리한 시료들보다 높은 경향을 나타냈다. 이는 설탕처리로 인해 표 면에 얇은 결정막이 형성되었기 때문이다. 천연 항 갈변제인 ascorbic acid 처리는 다양한 과채류 가공에 널리 사용되고 있는데(Chung 등, 1999), ascorbic acid의 유무는 다래의 표 면 색도에 영향을 미쳐, $\mathrm{SUC3O}, \mathrm{SUC5O}, \mathrm{SOR} 3 \mathrm{O}$ 에서 L*, $\mathrm{b}$ *값이 높아지는 것을 확인하였다. Ascorbic acid는 이전 연구 에서 사과의 갈변을 억제하는 데 효과를 보였다(Rogas-Graü

Table 2. Physicochemical characteristics of hot-air dried Actinidia arguta by various pretreatment of osmotic dehydration

\begin{tabular}{|c|c|c|c|c|c|c|}
\hline \multirow{2}{*}{ Sample ${ }^{1)}$} & \multicolumn{6}{|c|}{ Physicochemical characteristics } \\
\hline & Crude protein $(\%)$ & $\mathrm{L}^{* 4)}$ & $a^{*}$ & $b^{*}$ & $\begin{array}{c}\text { Total soluble solids } \\
\text { ( }{ }^{\circ} \text { Brix) }\end{array}$ & $\mathrm{pH}$ \\
\hline CONT & $3.90 \pm 0.14^{2) \mathrm{ab} 3)}$ & $47.03 \pm 3.08^{\mathrm{de}}$ & $-1.45 \pm 0.60^{\mathrm{ab}}$ & $25.52 \pm 1.50^{\mathrm{de}}$ & $10.20 \pm 0.00^{\mathrm{a}}$ & $3.69 \pm 0.02^{\mathrm{e}}$ \\
\hline SUC3O & $3.93 \pm 0.46^{\mathrm{ab}}$ & $46.96 \pm 3.84^{\mathrm{de}}$ & $-1.15 \pm 0.85^{\mathrm{bc}}$ & $24.73 \pm 2.36^{\mathrm{cd}}$ & $11.07 \pm 0.06^{\mathrm{b}}$ & $3.59 \pm 0.01^{\mathrm{a}}$ \\
\hline SUC3X & $3.67 \pm 0.87^{\mathrm{ab}}$ & $46.08 \pm 2.09^{\mathrm{cd}}$ & $-1.04 \pm 0.38^{\mathrm{bc}}$ & $24.22 \pm 2.28^{\mathrm{cd}}$ & $11.73 \pm 0.12^{\mathrm{c}}$ & $3.68 \pm 0.01^{\mathrm{de}}$ \\
\hline SUC5O & $3.42 \pm 0.54^{\mathrm{a}}$ & $48.99 \pm 2.72^{\mathrm{e}}$ & $-1.79 \pm 0.57^{\mathrm{a}}$ & $26.59 \pm 1.99^{\mathrm{e}}$ & $13.17 \pm 0.06^{\mathrm{d}}$ & $3.64 \pm 0.01^{\mathrm{c}}$ \\
\hline SUC5X & $3.82 \pm 0.23^{\mathrm{ab}}$ & $46.09 \pm 3.68^{\mathrm{cd}}$ & $-0.78 \pm 1.18^{\mathrm{cd}}$ & $25.17 \pm 2.66^{\mathrm{cde}}$ & $11.13 \pm 0.06^{\mathrm{b}}$ & $3.66 \pm 0.02^{\mathrm{cdc}}$ \\
\hline SOR3O & $3.86 \pm 0.18^{\mathrm{ab}}$ & $44.02 \pm 3.82^{\mathrm{bc}}$ & $-1.21 \pm 0.53^{\mathrm{abc}}$ & $23.56 \pm 3.07^{\mathrm{bc}}$ & $11.93 \pm 0.06^{\mathrm{c}}$ & $3.63 \pm 0.01^{\mathrm{bc}}$ \\
\hline SOR3X & $5.02 \pm 0.63^{\mathrm{b}}$ & $41.13 \pm 3.59^{\mathrm{a}}$ & $-0.29 \pm 1.51^{\mathrm{d}}$ & $22.02 \pm 1.67^{\mathrm{ab}}$ & $14.97 \pm 0.58^{\mathrm{f}}$ & $3.69 \pm 0.05^{\mathrm{e}}$ \\
\hline SOR5O & $4.00 \pm 0.30^{\mathrm{ab}}$ & $41.09 \pm 2.97^{\mathrm{a}}$ & $-0.61 \pm 1.05^{\mathrm{cd}}$ & $21.91 \pm 2.64^{\mathrm{a}}$ & $14.40 \pm 0.35^{\mathrm{e}}$ & $3.65 \pm 0.01^{\mathrm{cd}}$ \\
\hline SOR5X & $3.14 \pm 1.69^{\mathrm{a}}$ & $42.26 \pm 2.13^{\mathrm{ab}}$ & $-1.09 \pm 0.76^{\mathrm{bc}}$ & $22.36 \pm 1.64^{\mathrm{ab}}$ & $14.53 \pm 0.31^{\mathrm{e}}$ & $3.60 \pm 0.01^{\mathrm{ab}}$ \\
\hline
\end{tabular}

${ }^{1)} \mathrm{CONT}$, no treatment; SUC3O, sucrose $50{ }^{\circ}$ Brix solution with ascorbic acid $2 \%$ in $30^{\circ} \mathrm{C}$; SUC $3 \mathrm{X}$, sucrose $50{ }^{\circ} \mathrm{Brix}$ solution in $30^{\circ} \mathrm{C}$; SUC5O, sucrose $50{ }^{\circ}$ Brix solution with ascorbic acid $2 \%$ in $55^{\circ} \mathrm{C}$; SUC5X, sucrose $50{ }^{\circ}$ Brix solution in $55^{\circ} \mathrm{C}$; SOR $3 \mathrm{O}$, sorbitol $50{ }^{\circ}$ Brix solution with ascorbic acid $2 \%$ in $30^{\circ} \mathrm{C}$; SOR $3 \mathrm{X}$, sorbitol $50^{\circ}$ Brix solution in $30^{\circ} \mathrm{C}$; SOR5O, sorbitol $50^{\circ}$ Brix solution with ascorbic acid $2 \%$ in $55^{\circ} \mathrm{C}$; SOR5X, sorbitol $50{ }^{\circ}$ Brix solution in $55^{\circ} \mathrm{C}$.

${ }^{2)}$ Values are mean $\pm \mathrm{SD}$ (crude protein, total soluble solids and $\mathrm{pH} ; \mathrm{n}=3, \mathrm{~L}^{*}, \mathrm{a}^{*}$ and $\mathrm{b}^{*} ; \mathrm{n}=18$ ).

${ }^{3)}$ Values followed by different uppercase letter $\left({ }^{\mathrm{a}-\mathrm{f}}\right)$ within a column are significantly different at $\mathrm{p}<0.05$ based on Duncan's multiple rage test.

${ }^{4} L^{*}$, lightness; $a^{*}$, redness; $b^{*}$, yellowness. 
등, 2006). 처리 온도는 표면 색도에 크게 영향을 주지 않았 으며, 4번을 제외하고 무처리구보다 어두운 색으로 변색되었 다. $\mathrm{SUC5O}$ 은 lightness, greenness가 가장 높아, 밝은 초록빛 을 나타내었다. SUC5O는 높은 온도에서 ascorbic acid와 설 탕의 막 형성 두 가지에 모두 영향을 받으며, 색이 가장 밝고 기호성이 높게 나타났을 것으로 보인다.

\section{가용성 고형분 및 $\mathrm{pH}$}

가용성 고형분, $\mathrm{pH}$ 분석 결과는 Table 2 에 나타내었다. 가 용성 고형분 함량은 수분함량 차이에 영향을 받게 된다. 무처 리구가 가용성 고형분 함량이 $10.20^{\circ} \mathrm{Brix}$ 으로 가장 낮았으 며, SOR3X, SOR5O, SOR5X가 14.40-14.97 ${ }^{\circ}$ Brix로 다른 처리구보다 유의적으로 높았다. Ascorbic acid 병용처리는 가 용성 고형분 함량에 영향을 주지 않았다. $\mathrm{SUC5O}$ 는 수분함 량도 다른 설탕 전처리 시료보다 낮았으며, 가용성 고형분 함 량은 높았다. 또한 대체적으로 가용성 고형분 함량와 $\mathrm{L} *$ 값과 반비례하게 나타나, 가용성 고형분이 높을수록, 건조 후 갈변 이 많이 된 것을 볼 수 있었다. $\mathrm{pH}$ 는 시료별 유의적 차이가 크게 나지 않았으며, 경향성도 나타나지 않았다. 하지만 무처 리구 보다는 조금씩 $\mathrm{pH}$ 가 감소한 것을 볼 수 있었으나 유의적 이지는 않았다. 따라서 당 삼투전처리와 처리 온도, ascorbic acid 유무는 다래의 $\mathrm{pH}$ 에 크게 영향을 주지 않을 것으로 보 인다. 이는 ascorbic acid 병용 처리한 사과의 가용성 고형분 함량과 $\mathrm{pH}$ 가 다른 처리구와 유의적 차이가 없다는 Kim 등 (2011b)의 결과와 유사하였다.

\section{유리당 함량}

당 삼투 전처리한 열풍건조 다래의 유리당 함량은 Table 3 에 나타내었다. 모든 시료의 유리당 함량은 fructose, glucose, sucrose 순으로 검출되었다. Sucrose 함량은 대조구에 비하여 삼투처리 구들이 모두 높게 나타나는 것을 확인하였다. 유리 당 변화를 보면 sucrose가 가장 많이 증가하였는데, 이는 삼투 건조 시 용매로 설탕을 사용했기 때문이라고 생각되며, glucose 는 약간의 증가를 보였다. Lenart(1994)는 삼투건조 후 유리 당의 조성 중 sucrose와 다당류가 점차 증가한다고 보고하였 다. $\mathrm{SUC} 3 \mathrm{O}, \mathrm{SUC} 3 \mathrm{X}, \mathrm{SOR} 3 \mathrm{O}, \mathrm{SOR} 3 \mathrm{X}$ 가 $\mathrm{SUC5O}, \mathrm{SUC5X}$, SOR5O, SOR5X에 비해 sucrose가 높게 나타났는데, 이는 높은 온도에서 효소작용 등으로 인해 sucrose가 단당류로 분해 되어 감소한 것으로 보인다. $\operatorname{Kim}(2004)$ 은 sucrose의 분해산물 인 glucose와 fructose는 증가할 수 있다(Kim, 2004)고 언급하 였으나, 본 연구에서는 그러한 경향성을 크게 보이지 않았다. Dixon과 Jen(1977)의 보고에 의하면 glucose의 변화는 sucrose 의 가수분해에 의한 것보다는 starch의 분해에 의한 것일 수 있 다. 설탕 삼투 처리의 경우, 총 당의 함량은 온도가 증가할수록 높게 나타나 삼투효과가 커짐을 알 수 있었다. 온도가 높아짐에 따라 용질의 흐름이 활발해져 총 당량이 증가한 것인데, 이러한 결과는 Youn 등(1996)의 연구결과와 유사하였다.

\section{물성}

다양한 건조다래의 물성은 Table 4에 나타내었다. 다래류 의 물성은 수분 함량의 변화, 전분과 당, 단백질 등의 저장

Table 3. Free sugar contents of hot-air dried Actinidia arguta by various pretreatment of osmotic dehydration

\begin{tabular}{cccc}
\hline & & Free sugar $(\mathrm{ppm})$ & \\
Sample & & Glucose & Sucrose \\
\cline { 2 - 4 } & Fructose & $11,191.32 \pm 927.56^{\mathrm{a}}$ & $126.48 \pm 5.52^{\mathrm{a}}$ \\
CONT & $13,605.82 \pm 1,048.59^{2) \mathrm{a} 3)}$ & $12,534.58 \pm 703.43^{\mathrm{b}}$ & $518.60 \pm 8.91^{\mathrm{e}}$ \\
SUC3O & $14,708.10 \pm 792.20^{\mathrm{a}}$ & $12,386.19 \pm 197.51^{\mathrm{b}}$ & $348.75 \pm 83.61^{\mathrm{d}}$ \\
SUC3X & $14,715.83 \pm 506.74^{\mathrm{a}}$ & $15,944.00 \pm 134.09^{\mathrm{e}}$ & $340.14 \pm 22.86^{\mathrm{cd}}$ \\
SUC5O & $18,034.09 \pm 88.05^{\mathrm{c}}$ & $14,074.98 \pm 964.18^{\mathrm{c}}$ & $236.32 \pm 58.98^{\mathrm{bc}}$ \\
SUC5X & $16,560.24 \pm 1,090.02^{\mathrm{b}}$ & $14,564.66 \pm 193.75^{\mathrm{cd}}$ & $769.08 \pm 118.73^{\mathrm{f}}$ \\
SOR3O & $17,921.94 \pm 201.06^{\mathrm{c}}$ & $15,173.60 \pm 312.08^{\mathrm{de}}$ & $549.27 \pm 75.15^{\mathrm{e}}$ \\
SOR3X & $18,985.64 \pm 460.22^{\mathrm{c}}$ & $15,755.37 \pm 716.48^{\mathrm{e}}$ & $341.64 \pm 38.99^{\mathrm{cd}}$ \\
SOR5O & $17,811.87 \pm 700.17^{\mathrm{c}}$ & $13,031.50 \pm 65.30^{\mathrm{b}}$ & $211.86 \pm 9.79^{\mathrm{ab}}$ \\
SOR5X & $16,519.17 \pm 235.49^{\mathrm{b}}$ & & \\
\hline
\end{tabular}

${ }^{1)} \mathrm{CONT}$, no treatment; SUC3O, sucrose $50{ }^{\circ}$ Brix solution with ascorbic acid $2 \%$ in $30^{\circ} \mathrm{C}$; SUC3X, sucrose 50 Brix solution in $30^{\circ} \mathrm{C}$; SUC5O, sucrose $50{ }^{\circ} \mathrm{Brix}$ solution with ascorbic acid $2 \%$ in $55^{\circ} \mathrm{C}$; SUC5X, sucrose $50{ }^{\circ} \mathrm{Brix}$ solution in $55^{\circ} \mathrm{C}$; SOR3O, sorbitol $50{ }^{\circ} \mathrm{Brix}$ solution with ascorbic acid $2 \%$ in $30^{\circ} \mathrm{C}$; SOR3X, sorbitol $50{ }^{\circ}$ Brix solution in $30^{\circ} \mathrm{C}$; SOR5O, sorbitol $50{ }^{\circ}$ Brix solution with ascorbic acid $2 \%$ in $55^{\circ} \mathrm{C}$; SOR5X, sorbitol $50{ }^{\circ}$ Brix solution in $55^{\circ} \mathrm{C}$.

${ }^{2)}$ Values are mean $\pm \mathrm{SD}(\mathrm{n}=3)$.

${ }^{3)}$ Values followed by different uppercase letter $\left({ }^{\mathrm{a}-\mathrm{f}}\right)$ within a column are significantly different at $\mathrm{p}<0.05$ based on Duncan's multiple rage test. 
Table 4. Texture properties of hot-air dried Actinidia arguta by various pretreatment of osmotic dehydration

\begin{tabular}{|c|c|c|c|c|c|c|c|}
\hline \multirow[b]{2}{*}{ Sample ${ }^{1)}$} & \multicolumn{7}{|c|}{ Texture properties } \\
\hline & $\begin{array}{l}\text { Strength } \\
\left(\mathrm{gf} / \mathrm{cm}^{2}\right)\end{array}$ & $\begin{array}{l}\text { Hardness } \\
\left(\mathrm{gf} / \mathrm{cm}^{2}\right)\end{array}$ & $\begin{array}{c}\text { Springness } \\
(\%)\end{array}$ & $\begin{array}{c}\text { Cohesiveness } \\
(\%)\end{array}$ & $\underset{\text { (gf) }}{\text { Gumminess }}$ & $\begin{array}{l}\text { Brittleness } \\
\text { (gf) }\end{array}$ & $\begin{array}{l}\text { Adhesiveness } \\
\text { (gf) }\end{array}$ \\
\hline CONT & $235.43 \pm 99.18^{2 \mathrm{abc} 3)}$ & $882.96 \pm 372.08^{\mathrm{abc}}$ & $72.80 \pm 1.79^{\mathrm{a}}$ & $60.06 \pm 3.77^{\mathrm{ab}}$ & $623.17 \pm 237.01^{\mathrm{ab}}$ & $453.40 \pm 170.16^{\mathrm{a}}$ & $-1.20 \pm 1.10^{\mathrm{d}}$ \\
\hline SUC3O & $203.42 \pm 52.42^{\mathrm{ab}}$ & $762.84 \pm 196.65^{\mathrm{ab}}$ & $78.40 \pm 2.19^{\mathrm{a}}$ & $65.04 \pm 3.55^{\mathrm{bc}}$ & $598.83 \pm 173.96^{\mathrm{ab}}$ & $469.36 \pm 138.96^{\mathrm{a}}$ & $-20.80 \pm 7.92^{\mathrm{bc}}$ \\
\hline SUC3X & $274.12 \pm 90.39^{\mathrm{abc}}$ & $1,027.84 \pm 338.72^{\mathrm{abc}}$ & $74.40 \pm 4.56^{\mathrm{a}}$ & $59.36 \pm 3.58^{\mathrm{a}}$ & $728.08 \pm 232.43^{\mathrm{ab}}$ & $542.56 \pm 180.65^{\mathrm{a}}$ & $-19.00 \pm 7.58^{\mathrm{bc}}$ \\
\hline SUC5O & $194.98 \pm 63.65^{\mathrm{ab}}$ & $731.18 \pm 238.64^{\mathrm{ab}}$ & $96.00 \pm 27.13^{b}$ & $66.10 \pm 5.37^{\mathrm{c}}$ & $576.80 \pm 180.59^{\mathrm{ab}}$ & $544.60 \pm 179.95^{\mathrm{a}}$ & $-79.40 \pm 23.73^{\mathrm{a}}$ \\
\hline SUC5X & $175.19 \pm 89.78^{\mathrm{a}}$ & $657.06 \pm 336.85^{\mathrm{a}}$ & $80.00 \pm 4.90^{\mathrm{ab}}$ & $63.84 \pm 2.53^{\mathrm{abc}}$ & $499.04 \pm 252.19^{\mathrm{a}}$ & $396.15 \pm 198.67^{\mathrm{a}}$ & $-11.40 \pm 11.72^{\mathrm{cd}}$ \\
\hline SOR3O & $263.20 \pm 71.71^{\mathrm{abc}}$ & $987.14 \pm 269.05^{\mathrm{abc}}$ & $76.00 \pm 5.66^{\mathrm{a}}$ & $61.58 \pm 1.95^{\mathrm{abc}}$ & $729.66 \pm 204.79^{\mathrm{ab}}$ & $553.53 \pm 158.10^{\mathrm{a}}$ & $-23.00 \pm 5.34^{\mathrm{bc}}$ \\
\hline SOR3X & $315.74 \pm 103.65^{\mathrm{bc}}$ & $1,183.84 \pm 388.56^{\mathrm{bc}}$ & $71.20 \pm 1.79^{\mathrm{a}}$ & $61.72 \pm 3.70^{\mathrm{abc}}$ & $865.80 \pm 246.87^{b}$ & $615.37 \pm 173.13^{\mathrm{a}}$ & $-31.00 \pm 11.66^{\mathrm{b}}$ \\
\hline SOR5O & $280.22 \pm 62.39^{\mathrm{abc}}$ & $1,051.00 \pm 234.01^{\mathrm{abc}}$ & $83.20 \pm 20.67^{\mathrm{ab}}$ & $62.18 \pm 4.13^{\mathrm{abc}}$ & $775.94 \pm 133.00^{\mathrm{ab}}$ & $657.41 \pm 258.74^{\mathrm{a}}$ & $-25.40 \pm 12.12^{\mathrm{bc}}$ \\
\hline SOR5X & $331.18 \pm 93.56^{\mathrm{c}}$ & $1,242.06 \pm 350.98^{\mathrm{c}}$ & $72.80 \pm 5.22^{\mathrm{a}}$ & $60.08 \pm 2.71^{\mathrm{ab}}$ & $887.11 \pm 216.44^{\mathrm{b}}$ & $638.43 \pm 124.75^{\mathrm{a}}$ & $-27.60 \pm 5.77^{\mathrm{bc}}$ \\
\hline
\end{tabular}

${ }^{1)} \mathrm{CONT}$, no treatment; SUC3O, sucrose $50^{\circ}$ Brix solution with ascorbic acid $2 \%$ in $30^{\circ} \mathrm{C}$; SUC $3 \mathrm{X}$, sucrose $50{ }^{\circ}$ Brix solution in $30^{\circ} \mathrm{C}$; SUC5O, sucrose $50{ }^{\circ}$ Brix solution with ascorbic acid $2 \%$ in $55^{\circ} \mathrm{C}$; SUC5X, sucrose $50{ }^{\circ}$ Brix solution in $55^{\circ} \mathrm{C}$; SOR3O, sorbitol $50{ }^{\circ}$ Brix solution with ascorbic acid $2 \%$ in $30^{\circ} \mathrm{C}$; SOR $3 \mathrm{X}$, sorbitol $50^{\circ}$ Brix solution in $30^{\circ} \mathrm{C}$; SOR5O, Sorbitol $50{ }^{\circ}$ Brix solution with ascorbic acid $2 \%$ in $55^{\circ} \mathrm{C}$; SOR $5 \mathrm{X}$, sorbitol $50^{\circ}$ Brix solution in $55^{\circ} \mathrm{C}$.

${ }^{2)}$ Values are mean \pm SD $(n=5)$.

${ }^{3)}$ Values followed by different uppercase letter $\left({ }^{\mathrm{a}-\mathrm{d}}\right)$ within a column are significantly different at $\mathrm{p}<0.05$ based on Duncan's multiple rage test.

산물의 변화로 변화할 수 있다(Lim 등, 2017). 전반적으로 strength, hardness, gumminess, brittleness는 솔비톨 전처리 시 값이 높았다. Springness, cohesiveness은 유의적 차이가 나타나지 않고 유사한 것으로 나타났다. 설탕 삼투 시에는 낮 은 온도 처리구에서 경도, 강도가 높게 나타나 단단한 식감을 나타냈으나, 솔비톨 삼투 시에는 반대로 처리 온도가 높을수 록 경도와 강도가 높게 나타났다. SUC3X를 제외한 설탕 삼 투처리는 무처리보다 strength hardnesss, gumminess가 낮아, 설탕 전처리가 오히려 건조제품을 부드럽게 해주는 것으로 보인다. 가공식품에서 설탕은 단맛을 제공하는 감미료로서의 역할뿐만 아니라, 최종 제품에 바람직한 물성을 제공하는 기 능소재로서 역할로 적용이 되고 있다. 히드록실(hydroxyl)에 서 기인한 탁월한 흡습성으로 제품에 보습효과를 줄 수 있다 (BeMiller와 Huber, 2008). 또한 전반적으로 ascorbic acid를 첨가했을 때 물성 값이 더욱 낮아졌다. 따라서 ascorbic acid 와 감미료 종류는 당삼투 시 건조 다래의 전반적인 물성에 영향을 주는 것으로 보인다.

\section{항산화능}

$\mathrm{DPPH}$ 라디칼 소거능과 TFC를 분석한 결과는 Fig. 2에 나 타내었다. DPPH 라디칼 소거능은 SUC3O, SUC5O, SOR5O 가 무처리구보다 높은 것을 확인했으며, 이들은 모두 ascorbic $\mathrm{acid}$ 를 첨가하였다는 공통점이 있었다. 이러한 결과는 ascorbic acid 침지 처리 시 감자의 DPPH 소거능이 높다는 Son 등 (2014)의 연구 결과와 일치하였다. 반면, ascorbic acid를 첨
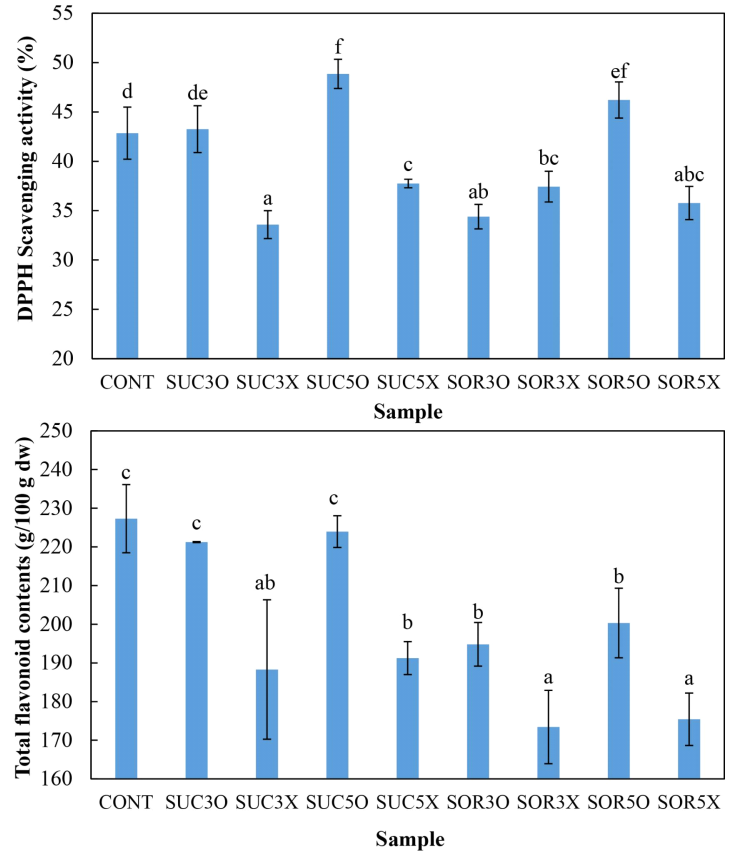

Fig. 2. Antioxidant activity of hot-air dried Actinidia arguta by various pretreatment of osmotic dehydration.

CONT, no treatment; SUC3O, sucrose $50{ }^{\circ}$ Brix solution with ascorbic acid $2 \%$ in $30^{\circ} \mathrm{C}$; SUC3X, sucrose $50{ }^{\circ}$ Brix solution in $30^{\circ} \mathrm{C}$; SUC5O, sucrose $50{ }^{\circ}$ Brix solution with ascorbic acid $2 \%$ in $55^{\circ} \mathrm{C}$; SUC5X, sucrose $50^{\circ}$ Brix solution in $55^{\circ} \mathrm{C}$; SOR $3 \mathrm{O}$, sorbitol $50^{\circ}$ Brix solution with ascorbic acid $2 \%$ in $30^{\circ} \mathrm{C}$; SOR $3 \mathrm{X}$, sorbitol $50^{\circ}$ Brix solution in $30^{\circ} \mathrm{C}$; SOR5O, sorbitol $50{ }^{\circ}$ Brix solution with ascorbic acid $2 \%$ in $55^{\circ} \mathrm{C}$; SOR5X, sorbitol $50{ }^{\circ}$ Brix solution in $55^{\circ} \mathrm{C}$.

Values followed by different small letters $\left({ }^{\mathrm{a}-\mathrm{t}}\right)$ are significantly different at $\mathrm{p}<0.05$ based on Duncan's multiple range test according to the group. 
가하지 않은 처리구는 모두 무처리구보다 라디칼 소거능이 유의적으로 낮게 나타나는 것을 확인하였다. 또한 처리 온도 가 높을 때, $\mathrm{DPPH}$ 라디칼 소거능이 전반적으로 더 높은 것 을 확인할 수 있었으며, 이는 온도가 높을수록 다래의 항산화 능을 가진 유효성분보다 수분만 더 잘 빠져나온 것으로 볼 수 있다. 또한 전반적으로 설탕 삼투처리구들이 솔비톨 처리 구들에 비하여 DPPH 소거능이 비교적 높은 것을 확인 할 수 있었다. Lee 등(2017)은 당 종류를 달리한 생강정과의 TPC 함량이 당알코올인 자일리톨보다 설탕 사용 시 더 높았다고 보고하였다. 자일리톨은 솔비톨과 비슷한 성질의 당알코올이 므로, 유사한 경향이 나온 것으로 사료된다.

$\mathrm{TFC}$ 결과에서는 삼투 처리한 모든 시료들이 무처리구보다 낮은 함량을 나타냈다. 또한 DPPH 라디칼 소거능 결과와 경 향이 유사하게 전반적으로 설탕 삼투처리 시료가 솔비톨 전처 리 시료보다 함량이 높았다. 또한, 처리 온도가 높고 ascorbic $\mathrm{acid}$ 를 첨가한 시료가 그렇지 않은 시료보다 $\mathrm{TFC}$ 함량이 높 았다. 이는 ascorbic acid 처리 시 저장 중 사과의 TPC가 높게 유지되었다는 Jang과 Moon(2010)의 연구결과와 유사하였다.

따라서 위의 결과를 종합적으로 정리하였을 때, 전처리에 따른 건조다래의 항산화능 손실을 막기 위해서는 $55^{\circ} \mathrm{C}$ 에서 설 탕 및 ascorbic acid 삼투전처리가 가장 적절할 것으로 보인다.

\section{관능평가}

관능평가 결과는 Table 5에 나타내었다. 단맛 항목은 SUC5X, $\mathrm{SOR} 3 \mathrm{O}$ 를 제외하고는 유사한 점수를 받았다. $\mathrm{CONT}$ 은 상대 적으로 단맛이 적고 신맛이 많았다. 가용성 고형분 함량 측정
결과와 sweetness 항목 점수의 경향이 일치하지는 않았고, 미 세한 단맛의 차이는 못 느끼는 것으로 보인다. 건조 다래의 외관사진은 Fig. 3에 나타내었다. 모든 처리구가 당으로 인하 여 CONT에 없는 표면 광택이 나타났다. SUC구에 비하여 $\mathrm{SOR}$ 구들이 약간의 갈변이 진행되었고, 더욱 주름이 많고 수 축된 것을 확인할 수 있었다. 또한 간혹 당 결정이 발생한 것 을 볼 수 있다. Ascorbic acid 첨가가 외관에는 큰 영향을 주 지 않는 것으로 보인다. 관능검사 결과에서도 외관은 설탕 삼 투 전처리 샘플들이 비교적 높은 점수를 받았으며, 이는 솔비 톨 처리 시료들은 과육 수축이 많이 되어 형태가 변형되었기 때문이다. 식감과 냄새에 대한 기호도는 비슷하였다. 전반적 으로 무처리구와 SOR3O는 낮은 기호도를 나타냈으며, 이는 단맛이 적기 때문인 것으로 보인다. 조직감, 냄새 항목에서는 유의적 차이 없이 비슷한 기호도를 나타내었다. 전반적 기호 도에서 SUC5X가 가장 높은 점수를 받아, 단맛강도, 외관에 영향을 많이 받는 것으로 보인다. SUC5X는 조직감 분석 결과 에서 볼 수 있듯이, strength, hardness, gumminess, brittleness 가 가장 낮으므로 딱딱한 식감보다는 부드럽고 촉촉한 식감 을 더 선호하는 것으로 보인다. 따라서, $55^{\circ} \mathrm{C}$ 의 ascorbic acid 첨가 설탕 삼투 처리가 다래 열풍건조 제품으로 적절하다.

\section{요 약}

본 연구에서는 높은 기호성과 기능성을 가진 열풍건조다 래 제품을 개발하기 위하여 다양한 당삼투 전처리를 하고, 그 품질 특성을 비교하였다. 설탕 삼투처리에 비하여, 솔비톨 처 리 시 과육의 weight reduction(\%)이 높았으며, 수분함량이

Table 5. Sensory scores ( 7 hedonic) of hot-air dried Actinidia arguta by various pretreatment of osmotic dehydration

(unit: score)

\begin{tabular}{|c|c|c|c|c|c|c|}
\hline Samples ${ }^{1)}$ & Sweetness & Sourness & Appearance & Texture & Smell & Overall \\
\hline CONT & $4.00 \pm 1.00^{2) \mathrm{ab} 3)}$ & $5.00 \pm 0.87^{\mathrm{a}}$ & $4.67 \pm 0.50^{\mathrm{abc}}$ & $5.00 \pm 1.12^{\mathrm{a}}$ & $4.89 \pm 0.78^{\mathrm{a}}$ & $4.67 \pm 0.50^{\mathrm{a}}$ \\
\hline SUC3O & $4.44 \pm 1.13^{\mathrm{ab}}$ & $4.67 \pm 0.71^{\mathrm{a}}$ & $5.44 \pm 0.88^{\mathrm{cd}}$ & $5.22 \pm 0.97^{\mathrm{a}}$ & $4.89 \pm 0.93^{\mathrm{a}}$ & $5.33 \pm 0.71^{\mathrm{ab}}$ \\
\hline SUC3X & $4.33 \pm 1.12^{\mathrm{ab}}$ & $4.78 \pm 1.30^{\mathrm{a}}$ & $5.00 \pm 0.71^{\mathrm{bcd}}$ & $5.33 \pm 1.50^{\mathrm{a}}$ & $4.89 \pm 1.17^{\mathrm{a}}$ & $5.22 \pm 1.09^{\mathrm{ab}}$ \\
\hline SUC5O & $4.44 \pm 1.01^{\mathrm{ab}}$ & $4.00 \pm 1.32^{\mathrm{a}}$ & $5.33 \pm 1.00^{\mathrm{bcd}}$ & $5.33 \pm 1.32^{\mathrm{a}}$ & $5.00 \pm 0.71^{\mathrm{a}}$ & $5.11 \pm 0.93^{\mathrm{ab}}$ \\
\hline SUC5X & $4.78 \pm 1.56^{\mathrm{b}}$ & $4.33 \pm 0.71^{\mathrm{a}}$ & $5.56 \pm 0.73^{\mathrm{d}}$ & $5.89 \pm 0.78^{\mathrm{a}}$ & $4.78 \pm 0.67^{\mathrm{a}}$ & $5.67 \pm 0.87^{\mathrm{b}}$ \\
\hline SOR3O & $3.44 \pm 1.13^{\mathrm{a}}$ & $4.22 \pm 1.48^{\mathrm{a}}$ & $4.56 \pm 0.88^{\mathrm{ab}}$ & $5.00 \pm 1.22^{\mathrm{a}}$ & $4.78 \pm 0.44^{\mathrm{a}}$ & $4.67 \pm 0.87^{\mathrm{a}}$ \\
\hline SOR3X & $4.22 \pm 1.09^{\mathrm{ab}}$ & $4.00 \pm 1.32^{\mathrm{a}}$ & $4.00 \pm 1.00^{\mathrm{a}}$ & $5.33 \pm 1.22^{\mathrm{a}}$ & $4.67 \pm 0.87^{\mathrm{a}}$ & $5.00 \pm 1.00^{\mathrm{ab}}$ \\
\hline SOR5O & $4.44 \pm 1.24^{\mathrm{ab}}$ & $4.67 \pm 1.41^{\mathrm{a}}$ & $4.89 \pm 0.78^{\mathrm{bcd}}$ & $5.89 \pm 1.27^{\mathrm{a}}$ & $4.33 \pm 0.50^{\mathrm{a}}$ & $5.22 \pm 0.83^{\mathrm{ab}}$ \\
\hline SOR5X & $4.44 \pm 1.13^{\mathrm{ab}}$ & $4.33 \pm 1.32^{\mathrm{a}}$ & $4.89 \pm 0.78^{\mathrm{bcd}}$ & $5.11 \pm 1.17^{\mathrm{a}}$ & $4.78 \pm 0.97^{\mathrm{a}}$ & $5.11 \pm 1.05^{\mathrm{ab}}$ \\
\hline
\end{tabular}

${ }^{1)} \mathrm{CONT}$, no treatment; SUC3O, sucrose $50{ }^{\circ}$ Brix solution with ascorbic acid $2 \%$ in $30^{\circ} \mathrm{C}$; SUC $3 \mathrm{X}$, sucrose $50{ }^{\circ}$ Brix solution in $30^{\circ} \mathrm{C}$; SUC5O, sucrose $50{ }^{\circ}$ Brix solution with ascorbic acid $2 \%$ in $55^{\circ} \mathrm{C}$; SUC5X, sucrose $50{ }^{\circ}$ Brix solution in $55^{\circ} \mathrm{C}$; SOR $3 \mathrm{O}$, sorbitol $50{ }^{\circ} \mathrm{Brix}$ solution with ascorbic acid $2 \%$ in $30^{\circ} \mathrm{C}$; SOR3X, sorbitol $50{ }^{\circ}$ Brix solution in $30^{\circ} \mathrm{C}$; SOR5O, sorbitol $50{ }^{\circ}$ Brix solution with ascorbic acid $2 \%$ in $55^{\circ} \mathrm{C}$; SOR5X, sorbitol $50^{\circ}$ Brix solution in $55^{\circ} \mathrm{C}$.

${ }^{2)}$ Values are mean \pm SD $(\mathrm{n}=9)$.

${ }^{3)}$ Values followed by different uppercase letter $\left({ }^{\mathrm{a}-\mathrm{d}}\right)$ within a column are significantly different at $\mathrm{p}<0.05$ based on Duncan's multiple rage test. 


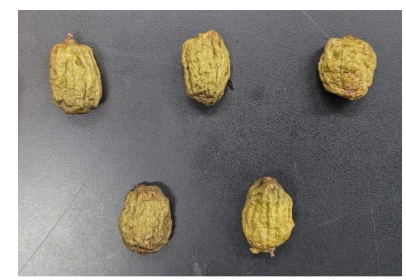

CONT

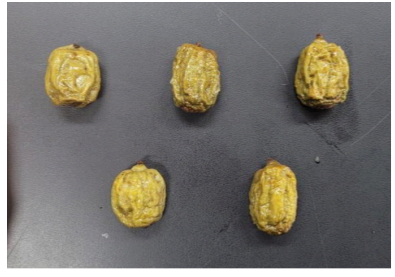

SUC3O

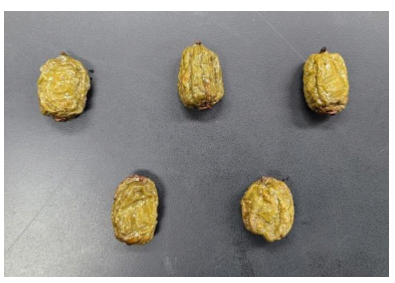

SOR3O

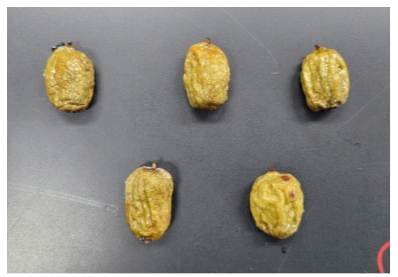

SUC3X

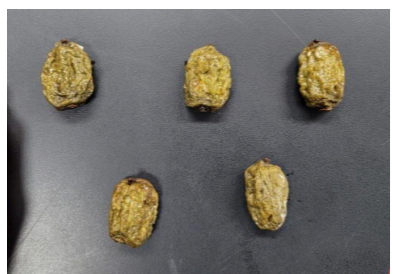

SOR3X

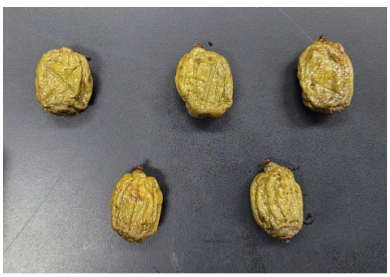

SUC5O

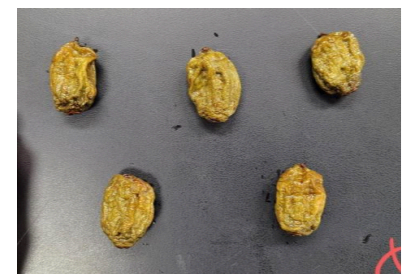

SOR5O

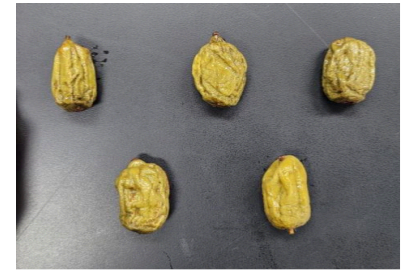

SUC5X

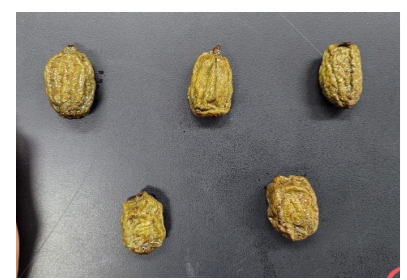

SOR5X

Fig. 3. Appearance of hot-air dried Actinidia arguta by various pretreatment of osmotic dehydration.

CONT, no treatment; SUC3O, sucrose $50{ }^{\circ}$ Brix solution with ascorbic acid $2 \%$ in $30^{\circ} \mathrm{C}$; SUC3X, sucrose $50{ }^{\circ}$ Brix solution in $30^{\circ} \mathrm{C}$; SUC5O, sucrose $50{ }^{\circ}$ Brix solution with ascorbic acid $2 \%$ in $55^{\circ}$; SUC5X, sucrose $50{ }^{\circ}$ Brix solution in $55^{\circ} \mathrm{C}$; SOR $3 \mathrm{O}$, sorbitol $50{ }^{\circ} \mathrm{Brix}$ solution with ascorbic acid $2 \%$ in $30^{\circ} \mathrm{C}$; SOR3X, sorbitol $50{ }^{\circ}$ Brix solution in $30^{\circ} \mathrm{C}$; SOR5O, sorbitol $50{ }^{\circ}$ Brix solution with ascorbic acid $2 \%$ in $55^{\circ} \mathrm{C}$; SOR5X, sorbitol $50{ }^{\circ}$ Brix solution in $55^{\circ} \mathrm{C}$.

낮은 것을 확인하여, 솔비톨을 당 삼투용액으로 사용 시 수분 및 유효성분 유출, 당침투가 잘 되는 것으로 사료된다. 또한 설탕 삼투처리구 중에서는 $55^{\circ} \mathrm{C}$ 의 ascorbic acid 첨가 용액 삼투처리구가 건조 효율이 높은 것으로 보인다. 또한 당 종류 와 상관없이 처리 온도가 높은 것이 수분 및 유효성분 유출을 많이 시키는 것으로 보인다. 설탕 전처리에 비하여 솔비톨 전 처리 시 과실의 색이 더 붉고, 어두워지는 경향이 나타났으 며, 가용성 고형분 함량이 높았다. 물성 분석 결과, 설탕 전처 리 시 hardness가 낮은 경향을 보이고 과육이 부드러웠다. 항 산화능 검사 시, 총 플라보노이드 함량과 DPPH 소거능은 설 탕 전처리 시료들이 높은 함량을 나타냈으며, 특히 ascorbic $\mathrm{acid}$ 를 첨가했을 시 유의적으로 높은 항산화능을 보였다. 관 능검사 결과, 단맛이나 신맛에 유의적인 차이를 느끼지 못했 으며, 외관항목에서 설탕 전처리 건조다래가 비교적 높은 점 수를 얻었다. 따라서 기호성과 기능성, 건조 효율성 모두를 갖춘 최적의 건조다래를 제조하기 위해서는 ascorbic acid가 첨가된 $55^{\circ} \mathrm{C}$ 의 설탕 당삼투 용액을 삼투건조 용액을 사용하 는 것이 적절할 것으로 보인다.

\section{감사의 글}

본 연구는 경상북도산림자원개발원의 2020년도 다래를 이 용한 가공제품 개발 민간위탁 공동연구 과제 지원에 의한 연 구용역으로 이루어진 것임.

\section{Conflict of interests}

The authors declare no potential conflict of interest.

\section{ORCID}

Ji-Young Choi https://orcid.org/0000-0002-7854-9277

Kwang-Deog Moon https://orcid.org/0000-0001-5277-3345

\section{References}

Ahmed I, Qazi IM, Jamal S. Developments in osmotic 
dehydration technique for the preservation of fruits and vegetables. Innovation Food Sci Energing Technol, 34, 29-43 (2016)

Bae SI, Choi JY, Lee HJ, Kim JY, Moon KD. The effect of osmotic dehydration pretreatment with sweeteners on the quality of dried aronia berries. Korean J Food Preserv, 27, 468-475 (2020)

BeMiller JN, Huber KC. Carbohydrates. In: Food Chemistry, Damodaran S, Parkin KL, Fennema OR (Editors). CRC Press, Boca Raton, FL, USA, p 84-154 (2008)

Brand-Williams W, Cuvelier ME, Berset C. Use of a free radical method to evaluate antioxidant activity. LWT-Food Sci Technol, 28, 25-30 (1995)

Chung HS, Chung SK, Choi JU. Low oxygen CA storage of 'Fuji' apples. Korean J Food Sci Technol, 31, 12751282 (1999)

Dev SRS, Raghavan VGS. Advancements in drying techniques for food, fiber, and fuel. Drying Technol, 30, 1147-1159 (2012)

Dixon GM, Jen JJ. Changes of sugars and acids of osmovac-dried apple slices. J Food Sci, 42, 1126-1127 (1977)

Fisk CL, Mcdaniel MR, Strik BC, Zhao Y. Physicochemical, sensory, and nutritive qualities of hardy kiwifruit (Actinidia arguta 'Ananasnaya') as affected by harvest maturity and storage. J Food Sci, 71, S204-S210 (2006)

Hong JH, Youn KS, Choi YH. Optimization for the process of osmotic dehydration for the manufacturing of dried kiwifruit. Korean J Food Sci Technol, 30, 348-355 (1998)

Jang $\mathrm{JH}$, Moon KD. Effect of combined treatment with ultrasound and ascorbic acid on the storage qualities of fresh-cut 'Jonathan' apples. Korean J Food Preserv, 17, 202-207 (2010)

Jin CR, Cho CH, Nam TG, Cho YS, Kim DO. Effects of hot air drying on the antioxidant capacity of Actinidia arguta $\times$ A. deliciosa cv. Mansoo, a Hardy kiwifruit. Korean J Food Sci Technol, 47, 539-543 (2015)

Kim AN, So SA, Park CY, Lee KY, Rahman MS, Choi SG. Effect of edible coating on hygroscopicity and quality characteristics of freeze-dried Korean traditional Actinidia (Actinidia arguta) cultivars snack. J Korean Soc Food Sci Nutr, 45, 1344-1350 (2016)
Kim GC, Lee SY, Kim KM, Kim Y, Kim JS, Kim HR. Quality characteristics of hot-air and freeze dried apples slices after osmotic dehydration. J Korean Soc Food Sci Nutr, 40, 848-852 (2011a)

Kim HD. The proximate composition, free sugars contents and sensory characteristics of demi-glace sauce according to the varying quantity of Omija added. J East Asian Soc Dietary Life, 14, 598-607 (2004)

Kim MH. Osmotic concentration of apples and its effect on browning reaction during air dehydration. J Korean Soc Food Nutr, 19, 121-126 (1990)

Kim SY, Cho JS, Jeong MC, Moon KD. Effects of combined treatment with high $\mathrm{CO}_{2}$ concentration and ascorbic acid on browning of fresh-cut 'Fuji' apples. Korean J Food Preserv, 18, 475-480 (2011b)

Lee MK, Kim SH, Ham SS, Lee SY, Chung CK, Kang IJ, $\mathrm{Oh} \mathrm{DH}$. The effect of far infrared ray-vacuum drying on the quality changes of Pimpinella brachycarpa. J Korean Soc Food Sci Nutr, 29, 561-567 (2000)

Lenart A. Minimal Processing of Foods and Process Optimization: An Interface Osmotic Dehydration of Fruits Before Drying. CRC Press Inc, Boca Raton, FL, USA, p 87 (1994)

Lewicki PP, Lenart A. Osmotic dehydration of fruits and vegetables. In: Handbook of Industrial Drying, Part 3, Mujumdar AS, Dekker M (Editors), Taylor \& Francis Group LLC, New York, NY, USA, p 665-681 (2006)

Lim YJ, Lim CK, Eorm SH. Changes in bioactive components, antioxidant radical scavenging activities, and cholinesterase inhibition activities in periodically harvested and post-harvested kiwifruits. Hortic Sci Technol, 36, 245-255 (2017)

Matuska M, Lenart A, Lazarides HN. On the use of edible coatings to monitor osmotic dehydration kinetics for minimal solids uptake. J Food Eng, 72, 85-91 (2006)

$\mathrm{Na}$ KM, Hong JH, Cha WS, Park JH, Oh SL, Cho YJ, Lee WY. Optimization of osmotic dehydration process for manufacturing a dried sweet pumpkin. J Korean Soc Food Sci Nutr, 33, 433-438 (2004)

Nowicka P, Wojdylo A, Lech K, Figiel A. Influence of osmodehydration pretreatment and combined drying method on the bioactive potential of sour cherry fruits. Food Bioprocess Technol, 8, 824-836 (2015)

Park YK, Han JG, Hwang SI, Kim SH, Kang MS. Changes 
of photosynthesis, leaf and fruit characteristics of Actinidia arguta and hybrid kiwi (A. arguta $\times A$. deliciosa) according to crown layer. J Korean For Soc, 100, 8-13 (2011)

Phisut N. Spray drying technique of fruit juice powder: Some factors influencing the properties of product. Int Food Res J, 19, 1297-1306 (2012)

Rojas-Grau MA, Sobrino-Lopez A, Tapia MS, Martin-Belloso

O. Browning inhibition in fresh-cut 'Fuji' apple slices by natural antibrowning agents. J Food Sci, 71, 59-65 (2006)
Saurel R, Raoult-wack AL, Guilbert S. Mass transfer phenomena during osmotic dehydration of apple I. Fresh plant tissue. Int J Food Sci Technol, 29, $531-542$ (1994)

Son HJ, Moon KD. Effects of combined argon gas treatment on the quality of fresh-cut potatoes. Korean J Food Preserv, 21, 163-169 (2014)

Youn KS, Lee JH, Choi YH. Changes of free sugar and organic acid in the osmotic dehydration process of apples. Korean J Food Sci Technol, 28, 1095-1103 (1996) 